\title{
ISOLATED TORSION OF BILATERAL FALLOPIAN TUBES COMBINED WITH TUBAL ENDOMETRIOSIS: A CASE REPORT
}

\author{
Su Yeon Lim, MD, Joon Cheol Park, MD, PhD, Jin Gon Bae, MD, Jong In Kim, MD, PhD, Jeong Ho Rhee, MD, PhD
}

Department of Obstetrics and Gynecology, Keimyung University School of Medicine, Daegu, Korea

\begin{abstract}
Torsion of the fallopian tube is less frequent. Indeed, isolated bilateral fallopian tube torsion is rare and often difficult to diagnose. The etiology of fallopian tube torsion is still uncertain, especially when this is not associated with torsion of the ovary. We present a case of the torsion of isolated bilateral fallopian tube combined with tubal endometriosis. A 30-year-old woman presented with chronic abdominal pain of 5-month duration and severe dysmenorrhea. Presumptive diagnosis by ultrasound and magnetic resonance imaging was both adnexal endometriosis. At laparoscopy, the fimbrial ends of both tubes were dilated, twisted and necrotic changes with adhesion to omentum, which subsequently led to terminal obstruction of that tube. However, both ovaries and uterus were normal. Laparoscopic bilateral salpingectomy was performed. The postoperative histological report confirmed hematosalpinx with tubal endometriosis. To our knowledge, this is the first case of isolated and bilateral fallopian tubes torsion combined with tubal endometriosis.
\end{abstract}

Keywords: Fallopian tube; Torsion; Endometriosis; Laparoscopy; Salpingectomy

Torsion of the fallopian tube is less frequent but significant cause of lower abdominal pain in reproductive age women that is difficult to recognize preoperatively [1]. Although torsion of normal ovary or cystic ovary that generally involves the fallopian tube is relatively common, isolated torsion of the fallopian tube is still a poorly recognized clinical entity that remains a rare occurrence [2]. Also, there have been no specific symptoms, clinical findings, imaging or laboratory characteristics identified for this condition [3]. Therefore, most of cases with isolated fallopian tubal torsion had a delayed diagnosis and a subsequent delay of timely intervention that may result in failure to save tubal function.

We present a case of the torsion of isolated bilateral fallopian tube combined with tubal endometriosis in a 30-year-old woman that was successfully treated by laparoscopic bilateral salpingectomy.

\section{Case Report}

A 30-year-old woman (gravid, 0; para, 0) was referred to us for aggravation of dysmenorrhea during 5 months. Also, she presented with constant dull lower abdominal pain of 5-month duration. She was a virgin and had normal regular menstrual cycles. There was no bowel or urinary symptom. There was no significant medi- cal history, excluding appendectomy 15 years ago. On physical examination, no tenderness was observed. On pelvic examination by rectal, palpable mass with slight tenderness in both adnexa was noted. The transrectal ultrasonography demonstrated a normal uterus, both ovaries and evidenced the presence of round, thickwalled, complex cystic structures measuring $21 \times 21 \mathrm{~mm}, 53 \times 34$ $\mathrm{mm}$ adjacent to the right and left ovaries, respectively. Pelvic computed tomography (CT) and magnetic resonance image (MRI) (Fig. 1) confirmed the aforementioned findings as the pelvic endometriosis. In a view of the history for progressive dysmenorrhea and the psy-

Received: 2011. 9.15. Accepted: 2011.10.5.

Corresponding author: Jeong Ho Rhee, MD, PhD

Department of Obstetrics and Gynecology, Keimyung University

School of Medicine, 216 Dalseong-ro, Jung-gu, Daegu

700-712, Korea

Tel: +82-53-250-7871 Fax: +82-53-250-7599

E-mail: r1670416@dsmc.or.kr

This is an Open Access article distributed under the terms of the Creative Commons Attribution Non-Commercial License (http://creativecommons.org/licenses/ by-nc/3.0/) which permits unrestricted non-commercial use, distribution, and reproduction in any medium, provided the original work is properly cited.

Copyright (๑ 2012. Korean Society of Obstetrics and Gynecology 


\title{
KOREAN JOURNAL OF OBSTETRICS \& GYNECOLOGY
}

\author{
KJOG Vol. 55, No. 1, 2012
}

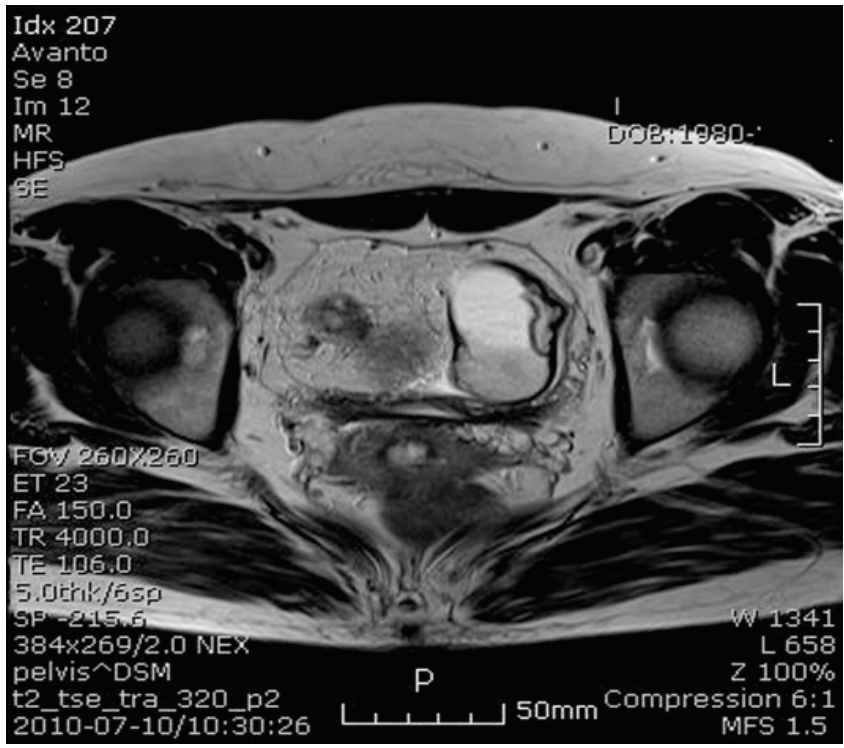

Fig. 1. Pelvic magnetic resonance imaging (MRI). Axial MRI view of the pelvis. chological impact on the patient, she was counseled and scheduled for diagnostic laparoscopy with the possibility of surgical intervention as deemed necessary. On laparoscopy, the right tube was observed to be twisted twice at its middle part and a thickwalled cystic dilatation at its distal portion that was adherent to the omentum. Symmetrically, the fimbrial end of the left tube was also occluded and three times twisted with congestion as a result, but the uterine isthmic aspect and the midsegment of the tube were identified and were not ischemic (Fig. 2A-2C). The both ovaries with normal appearance were not involved in the torsion and the uterus was normal. Endometriotic implant, such as spot, was only found on the left pelvic side wall. There were no other abnormal findings on laparoscopic abdominal inspection. A laparoscopic bilateral salpingectomy was performed after adhesiolysis (Fig. 2D). The histological examination revealed an extensive hemorrhagic infarction secondary to torsion and the hematosalpinx that endometrial gland was identified.
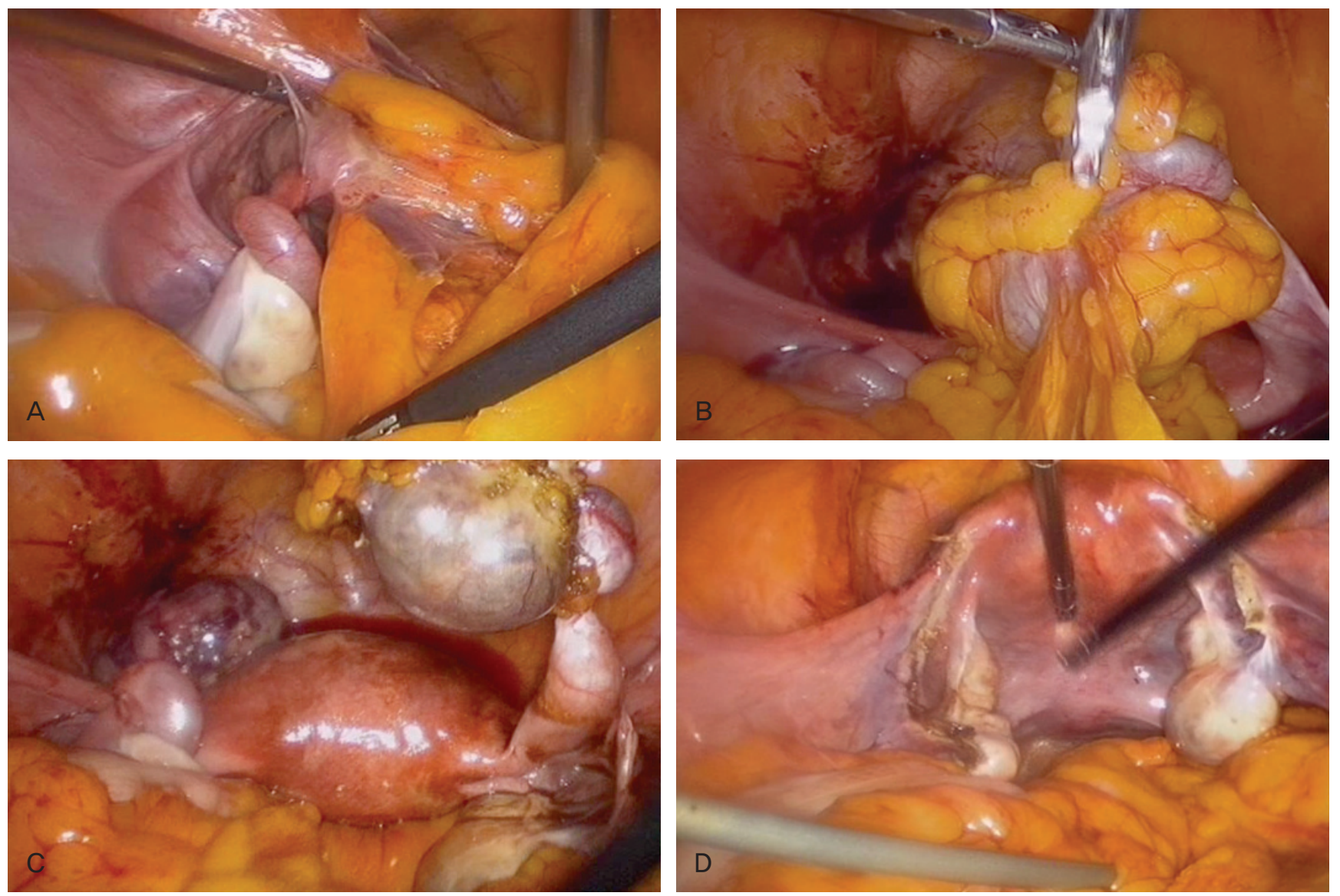

Fig. 2. Laparoscopic views. (A) The lesion of torsion of the left fallopian tube. The fimbrial end of the left tube was adherent to the omentum and pelvic wall. (B) Adhesion of the torted right fallopian tube with the omentum. (C) Laparoscopic pelvic overview after adhesiolysis shows bilateral torted tubes and cystic dilatation at the distal portion. (D) Laparoscopic pelvic overview after bilateral salpingectomy shows normal uterus and both ovaries. 


\title{
KOREAN JOURNAL OF OBSTETRICS \& GYNECOLOGY
}

\author{
Su Yeon Lim, et al. Isolated torsion of bilateral fallopian tubes
}

The postoperative course was uneventful and the patient was discharged home two days later. Until now, she remains well and asymptomatic at follow-up.

\section{Discussion}

Isolated fallopian tube torsion is a rare clinical event and the incidence is approximately one in 1.5 million reproductive aged women [2]. Most of the published case reports and occasional series concern unilateral torsion of the isolated fallopian tube. To the best of our knowledge, our case is the first report of isolated torsion of the bilateral fallopian tubes in a reproductive age woman. Our patient had tubal endometriosis which may have obstructed the fimbrial end of the tube and induced in hematosalpinx through retrograde menstruation [4].

The etiology or mechanism of isolated tubal torsion is still uncertain. However, proposed risk factors have been identified. Youssef et al. [5] suggested that intrinsic and extrinsic factors could possibly influence the occurrence of the torsion of isolated fallopian tube. The predisposing intrinsic factors include an excessive length and tortuosity of the tube, hydrosalpinx, hematosalpinx and pyosalpinx, previous sterilization, abnormal peristalsis or endometriosis, while extrinsic factors include paratubal mass, peritubal adhesion, or uterine enlargement compressing the fallopian tubes. Presumably, these factors create a pivot point around which the tube may twist one or several times [6].

The diagnosis of isolated fallopian tube torsion is easily missed preoperatively because of a lack of pathognomonic symptoms, specific findings on physical examination and adequate diagnostic tools. When torsion occurs, the patient usually experiences acute severe lower abdominal or pelvic pain. Pain may be constant or intermittent. Other sings of isolated tubal torsion are inconsistent and comprise anorexia, nausea, vomiting, or vaginal bleeding [7]. Pyrexia, tachycardia, or leukocytosis may be present. Indeed, the clinical presentation often resembles other causes of abdominal pain, for example ectopic pregnancy, pelvic inflammatory disease, ruptured ovarian cyst, hemorrhagic follicle, and acute appendicitis which are far more common. Although transvaginal ultrasound can easily identify enlarged adnexa and Color Doppler can also be used to demonstrate arterial and venous flow to adnexal structure, it must be emphasized that the presence or absence of flow cannot rule out fallopian torsion. CT and MRI are also useful in detecting twisted a vascular pedicle, thickened fallopian tubes, and hemorrhagic infarction. However, the sensitivity of these modalities of the isolated fallopian tube torsion has not yet to be determined [8]. Therefore, most of cases with isolated fallopian tubal torsion had a delayed diagnosis or the diagnosis was not made before surgical intervention because the clinical features are unspecific and objective findings are uncommon. Lo et al. [8] noted that in a total of 17 women with surgically proven isolated fallopian tube torsion, only three women had surgery within 12 hours, but 12 received surgery within seven days; the mean duration of lower abdominal pain until operation was $26.7 \pm 58.2$ days (range, 0.4 to 180 days). In our case, the time interval between the clinical presentation and postoperative diagnosis of isolated fallopian tube torsion was 5 months.

In the clinical setting of suspected adnexal torsion, emergent laparoscopy is critical to both diagnosis and fertility preservation. Several studies of adnexal torsion have demonstrated that the color, size, and degree of edema do not correlate with necrosis and subsequent return to normal tubal or ovarian function. Immediate detorsion is always recommended, because it is unclear how long a patient has until irreversible damage occurs [6]. However, our patient had bilateral salpingectomy due to obstruction of the both tubal terminal ends and necrosis.

In conclusion, we suggest that in the differential diagnosis of lower abdominal pain in a reproductive age woman, isolated torsion of the fallopian tube should be considered, although it is the low incidence. To the best of our knowledge, our case is the first report of isolated torsion of the bilateral fallopian tubes combined with tubal endometriosis in a reproductive age woman.

\section{References}

1. Rizk DE, Lakshminarasimha B, Joshi S. Torsion of the fallopian tube in an adolescent female: a case report. J Pediatr Adolesc Gynecol 2002;15:159-61.

2. Comerci G, Colombo FM, Stefanetti M, Grazia G. Isolated fallopian tube torsion: a rare but important event for women of reproductive age. Fertil Steril 2008;90:1198. e23-5.

3. Wong SW, Suen SH, Lao T, Chung KH. Isolated fallopian tube torsion: a series of six cases. Acta Obstet Gynecol Scand 2010;89:1354-6

4. Ohara N, Narita F, Murao S. Isolated torsion of haematosalpinx associated with tubal endometriosis. J Obstet Gynaecol 2003;23:453-4.

5. Youssef AF, Fayad MM, Shafeek MA. Torsion of the fallopian tube. A clinico-pathological study. Acta Obstet Gynecol Scand 


\section{KOREAN JOURNAL OF OBSTETRICS \& GYNECOLOGY}

KJOG Vol. 55, No. 1, 2012

1962;41:292-309.

6. Phillips K, Fino ME, Kump L, Berkeley A. Chronic isolated fallopian tube torsion. Fertil Steril 2009;92:394.e1-3.

7. van der Zanden M, Nap A, van Kints M. Isolated torsion of the fallopian tube: a case report and review of the literature. Eur J
Pediatr 2011;170:1329-32.

8. Lo LM, Chang SD, Lee CL, Liang CC. Clinical manifestations in women with isolated fallopian tubal torsion; a rare but important entity. Aust N Z J Obstet Gynaecol 2011;51:244-7.

\section{자궁내막증을 동반한 단독 양측성 난관 염전}

\section{계명대학교 의과대학 산부인과학교실}

임수연, 박준철, 배진곤, 김종인, 이정호

난관 염전은 흔하지 않은 질환이다. 게다가 단독 양측성 난관 염전은 매우 드물고 진단하기도 어렵다. 난관 염전에 대한 정확한 원인에 대해서는 아직까지 알려져 있지 않고 특히 난소과 관련이 없는 단독 난관 염전인 경우에 더욱 그러하다. 우리는 난관의 자궁내막증이 동 반된 단독 양측성 난관 염전 1예를 경험하였기에 이를 보고하는 바이다. 30세 여자 환자는 5 개월간의 만성 하복부 통증과 심한 생리통을 주소로 내원하였다. 초음파 및 골반 자기공명영상상 양측 자궁부속기의 자궁내막증이 의심되었다. 복강경 수술 결과 양측 난관의 울혈 및 염전 소견을 보였고 장간막과의 유착과 난관 폐쇄를 동반하고 있었다. 양측 난소 및 자궁은 정상이었다. 복강경하 양측 난관 절제술을 시 행하였고 조직검사상 양측 난관의 자궁내막증을 동반한 출혈성 괴사 소견이 관찰되었다. 본 증례와 같이 난관 자궁내막증을 동반한 단독 양측성 난관 염전은 드물어 저자들의 문헌고찰에 의하면 국내에 보고된 경우는 본 증례가 최초이다.

중심단어: 난관, 염전, 자궁내막증, 복강경수술, 난관절제술 